\title{
Pemanfaatan Lingkungan Rumah dengan Penanaman Tanaman Hidroponik
}

\author{
Yeni Rafita Sihombing ${ }^{1}$,Sufika Sary ${ }^{2}$, Mila Yulia Herosian ${ }^{3}$ \\ 1,2,3, Universitas Prima Indonesia, Jalan Sekip, Medan, 20111, Indonesia
}

\section{ARTICLE INFORMATION}

Received: February 00, 00

Revised: March 00, 00

Available online: April 00, 00

\section{KEYWORDS}

Hidroponik, Pengetahuan, Peluang, Pendapatan

\section{CORRESPONDENCE}

Phone: 085262122938

E-mail: yenirafitasihombing@unprimdn.ac.id

\begin{abstract}
A B $\mathbf{S}$ T $\mathbf{R}$ A $\mathbf{C}$ T
Hidroponik merupakan cara menanam tanaman dengan menggunakan media tanam berupa air. Cara ini digemari karena kita tidak perlu pusing memikirkan memikirkan dimana tanaman akan ditanam kita dapat menggunakan bahan bekas dan dapat diletakkan dimanapun. Selain itu bercocok tanam dengan teknik hidroponik tergolong mudah dan dapat dilakukan siapa saja dan mengasah kreativitas untuk mengolah dan menciptakan media baru untuk bercocok tanam.

Dalam upaya membantu masyarakat di daerah Tanjung Gusta, Kecamatan Medan Helvetia dan pemerintah dalam peningkatan kesejahteraan masyarakat, teridentifikasi bahwa berkreasi dengan hidroponik pada skala kecil atau rumah tangga merupakan segmen yang baik untuk diberikan pemahaman dalam pengembangan kegiatan ini dikarenakan dapat menjadi peluang usaha dalam skala rumah tangga. Kegiatan penyuluhan pengabdian masyarakat yang dilakukan adalah memberikan informasi dan pelatihan menanam sayuran secara hidroponik sederhana dengan sistem sumbu (Wick System). Diharapkan nantinya, dengan bekal pengetahuan ini, para ibu rumah tangga dapat melakukannya di rumah masing-masing dan nantinya akan dapat dengan mudah menyediakan sayuran segar dan bebas pestisida bagi keluarganya, sekalipun pada area pekarangan yang terbatas, dan sekaligus dapat pula dijadikan peluang usaha untuk menambah pendapatan keluarga.
\end{abstract}

\section{PENDAHULUAN}

Desa Tanjung Gusta merupakan salah satu desa yang berada dalam cakupan Kecamatan Medan Helvetia, Kotamadya Medan, Propinsi Sumatra Utara, Indonesia. Dilihat dari kondisi objektif desa tanjung Gusta merupakan salah satu kecamatan yang mendapatkan prioritas dari Walikota dalam hal penanganan kawasan kumuh dengan sebaran penduduk terbanyak dibanding desa lain di Kecamatan Medan Helvetia. Sedangkan dilihat dari demografi penduduknya, desa Tanjung Gusta merupakan desa dengan jumlah penduduk perempuan lebih banyak. Saat ini desa Tanjung Gusta sedang berkembang menjadi pusat perdagangan dan pemukiman.

Dilihat dari sebaran mata pencarian penduduk desa Tanjung Gusta sangat beragam antara lain pegawai negeri sipil,tukang bangunan, supir kendaraan umum, tukang becak dan wirausaha. Sedangkan untuk perempuan kebanyakan bekerja paruh waktu pada industry rumah tangga seperti makanan ringan.

Berdasarkan hasil wawancara dengan beberapa penduduk yang pada umumnya adalah perempuan, bahwa mereka ingin sekali membantu ekonomi keluarga dengan memanfaatkan lahan sempit yang ada serta sisa waktu yang ada ketika mereka telah berada di rumah dengan lebih efektif. Oleh karena itu, Dalam upaya membantu masyarakat di daerah Tanjung Gusta, Kecamatan Medan Helvetia dan pemerintah dalam peningkatan kesejahteraan masyarakat, teridentifikasi bahwa berkreasi dengan hidroponik pada skala kecil atau rumah tangga merupakan segmen yang baik untuk diberikan pemahaman dalam pengembangan kegiatan ini dikarenakan dapat menjadi peluang usaha dalam skala rumah tangga.

Untuk itu berdasarkan deskripsi kondisi masyarakat diatas, maka tim Dosen PKM Universitas Prima Indonesia tergerak untuk melaksanakan kegiatan pelatihan cara pemanfaatan lingkungan rumah dengan penanaman tanaman hidroponik.

Selanjutnya yaitu proses sosialisasi dan pelatihan cara pemanfaatan lingkungan rumah dengan penanaman tanaman hidroponik mulai dari persiapan bahan dalam hal ini dapat memanfaatkan bahan bekas yang ada di sekitar lingkungan, pembibitan, perawatan hingga proses panen tanaman hidroponik.

\section{METODE}

Metode kegiatan pengabdian yang dilaksanakan adalah dengan observasi awal, penyuluhan dan pelatihan mengenai cara pemanfaatan lahan sempit dengan teknik menanam hidroponik. Kegiatan penyuluhan dan pelatihan meliputi :

a. Pembukaan dan perkenalan dengan ibu - ibu yang ada di Kelurahan Tanjung Gusta Kecamatan Medan Helvetia yang merupakan sasaran dari kegiatan yang akan dilakukan 
ISSN (Online) 2722-1083,

VOL 2 NO 1 OKTOBER 2020

b. Melakukan pengenalan tentang apa itu hidroponik dan bagaimana menanam tanaman dengan menggunakan teknik hidroponik serta tanaman apa apa saja yang bisa di tanam dengan menggunakan teknik hidroponik

c. Melakukan praktek penanaman tanaman hidroponik.

\section{HASIL DAN PEMBAHASAN}

Kegiatan pengabdian masyarakat dilakukan di Kelurahan Tanjung Gusta Kecamatan Medan Helvetia dilaksankaan pada bulan Desember 2020 bertempat di salah satu rumah warga. Kegiatan yang dilakukan adalah dengan mengajarkan masyarakat terkhusus ibu - ibu untuk memanfaatkan Lingkungan Rumah Dengan Penanaman Tanaman Hidroponik.

Kegiatan penyuluhan dilakukan dengan memanfaatkan lahan kosong yang ada di lingkunganrumah. Pemanfaatan ini dilakukan dengan melalui beberapa tahapa yaitu :

1. Tahap Persiapan meliputi :

a) Melakukan survey ke tempat pengabdian yang ada di Kelurahan Tanjung Gusta KecamatanMedan Helvetia

b) Mengajukan permohonan ijin kepada lurah Tanjung Gusta Kecamatan Medan Helvetia

c) Melakukan pengurusan administrasi (surat - menyurat)

d) Mempersiapkan alat dan bahan yang digunakan

2. Kegiatan Penyuluhan tentang pemanfaatan Lingkungan Rumah dengan Penanaman TanamanHidroponik

a) Pembukaan dan perkenalan dengan ibu - ibu yang ada di Kelurahan Tanjung Gusta Kecamatan Medan Helvetia yang merupakan sasaran dari kegiatan yang akan dilakukan

b) Melakukan pengenalan tentang apa itu hidroponik dan bagaimana menanam tanaman dengan menggunakan teknik hidroponik serta tanaman apa apa saja yang bisa di tanam dengan menggunakan teknik hidroponik

c) Melakukan praktek penanaman tanaman hidroponik dengan langkah sebagai berikut : Bahan yang dibutuhkan :
a) Rockwool
b) Tempat pelastik sebagai bak
c) Vitamin A dan B
d) Benih
e) Netpot
f) Densimeter (alat ukur vitamin A hidroponik)
g) Kain flane

1. Potong Rockwool ukuran $2 \times 3 \mathrm{~cm}$, basahi rockwool, bolongi tengahnya, isi bibit dengan ketentuan 1 bibit 1 petak rockwool

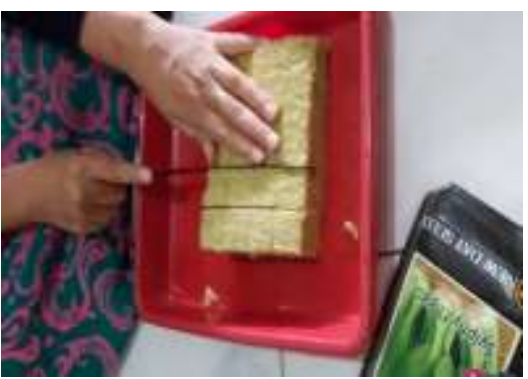

2. Setelah benih diisi ke dalam rockwool, tutup benih jika sdh diisi

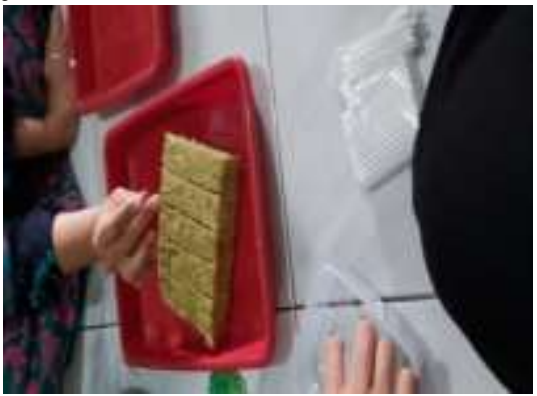

3. Jemur setiap hari sampai mau dipindahkan ke netpot

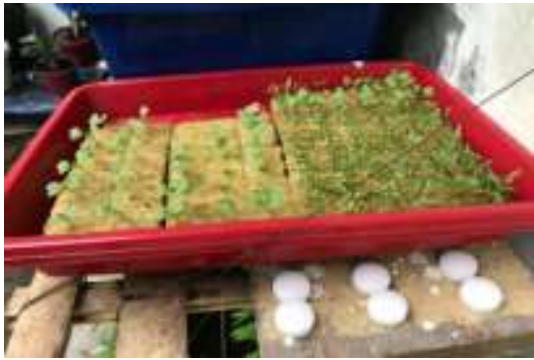

4. Isi bak sterofom dengan ukuran air $3 / 4$

5. Isi vitamin dengan takaran 1 minggu 500 ppm (untuk vitamin A dan vitamin B)

Jika 1 bulan, maka ukuran vitaminnya $1000-1200$ ppm

6. Jika sudah 7 hari sampai dengan 10 hari, barulah bisa dipindahkan ke netpot

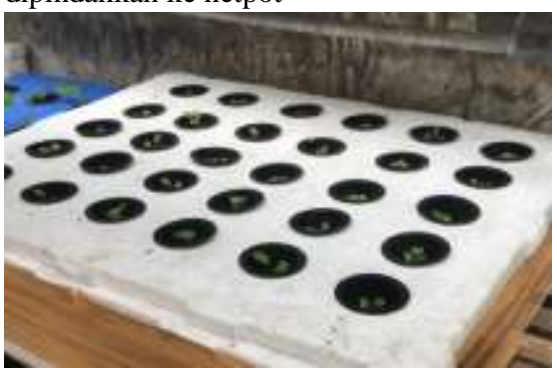


ISSN (Online) 2722-1083,

VOL 2 NO 1 OKTOBER 2020

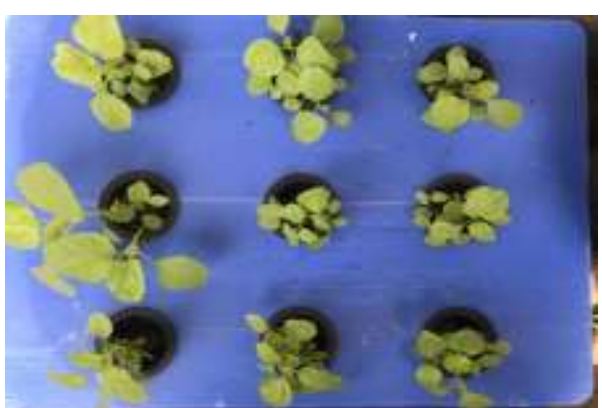

7. 3 hari sekali cek air dan cek vitamin

8. Tanaman siap dipanen 1,5 bulan

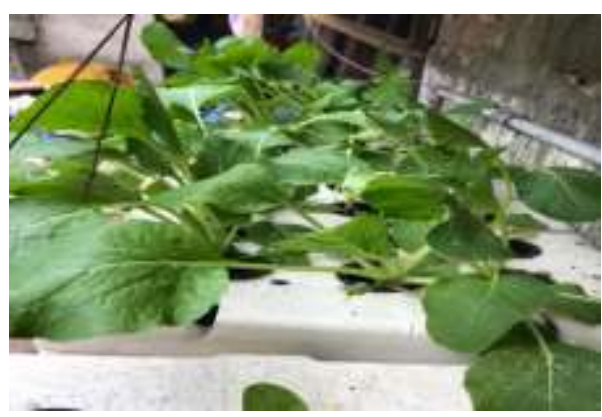

\section{KESIMPULAN}

1. Kegiatan pengabdian kepada masyarakat mengenai pemanfaatan lingkungan rumah dengan penanaman tanaman hidroponik di Kelurahan Tanjung Gusta Kecamatan Medan Helvetia telah terlaksana dengan baik

2. Kegiatan pengabdian kepada masyarakat mengenai pemanfaatan lingkungan rumah dengan penanaman tanaman hidroponik di Kelurahan Tanjung Gusta Kecamatan Medan Helvetia mendapatkan respon yang baik dan para ibu rumah tangga sangat antusias dalam mendengarkan pemaparan materi yang diberikan

3. Diperoleh 2 pertanyaan yang berasal dari ibu rumah tangga terkait materi tentang hidroponikdan para ibu rumah tangga mengharapkan ada pelatihan lanjutan terkait penanaman tanamanhidroponik.

\section{SARAN}

1. Kegiatan pengabdian seperti ini dapat dilakukan secara rutin baik di Kelurahan Tanjung Gusta maupun di lingkungan yang berbeda dengan sasaran masyarakat agar memiliki keahlian tambahan sehingga dapat semakin produktif dalam memanfaatkan waktu luang yang ada dan diharapkan juga dengan keahlian itu dapat membantu meningkatkan perekonomian keluarga.

2. Menjalin kerjasama dengan instansi yang memilki pengalaman dalam menanam tanaman hidroponik dalam sekala yang lebih besar.

\section{DAFTAR PUSTAKA}

Masduki, Anang (2017). Hidroponik Sebagai Sarana Pemanfaatan Lahan Sempit di Dusun Randubelang, Bangunharjo,Sewon, Bantul. Jurnal Pemberdayaan. Vol 1 No 2. Oktober 2017. Hal 185-192.

Roidah, Ida Syamsu (2014). Pemanfaatan Lahan dengan Menggunakan Sistem Hidroponik. Jurnal Universitas Tulungagung BONOROWO. Vol 1 No 2.

Riskawati., dkk (2020). PKM Budidaya Sayuran dengan Teknologi Hidroponik Bagi kelompok Tani (KWT). JCES (Journal of Character Education Society). Vol 3 No 3. Oktober 2020. Hal $639-650$. 